\title{
Issues pertaining to Wallachian and Moldavian voyvodas and their effect on Russo-Ottoman relations (1774-1806)
}

\author{
Akitsu Mayuzumi
}

\section{Introduction}

This article aims to present an aspect of Russo-Ottoman relations with regard to Wallachia and Moldavia in the period between 1774 and 1806, through an examination of issues surrounding the voyvodas (princes) as diplomatic issues between the two empires.

Beginning in the second half of the eighteenth century, close and complicated relations were established between Russia and the Ottoman Empire over Wallachia and Moldavia. Later, other European powers became involved as well. As a result, by the beginning of the nineteenth century, these two principalities occupied an important place in the power games of Europe and the Ottoman Empire, and issues regarding the voyvodas of these principalities became issues of significant interest to the European powers. Therefore, I believe that an analysis of this subject will help us to understand one aspect of the role played by these principalities in the process of the integration of Russia and the Ottoman Empire into the Western state system. Because the purpose of this article is to examine this aspect of integration, I will not consider matters pertaining to voyvodas in the context of domestic affairs. Rather, I will discuss this subject from the viewpoint of international relations.

After the Ottoman conquest, the historical experience of Wallachia and Moldavia, referred to as the Danubian Principalities in Western documents and important regions in present-day Romania, differed from those of other Balkan 
territories. Owing to their geographical and geopolitical position, these two principalities did not fall under the direct rule of the Porte but were under its control as autonomous vassal states, maintaining their partial independence in exchange for various obligations to the Porte, such as an annual tribute and the supply of provisions to Istanbul. Although Michael the Brave (Mihai Viteazul, 1558-1601) united Wallachia, Moldavia and Transylvania under a single rule for a short period of time in the end of the sixteenth century, in general, the Danubian Principalities were mostly under the control of the Porte during the sixteenth and seventeenth centuries. Thus, attempts made by the Poles and Austrians to interfere in the affairs of these two principalities seldom met with success.

However, the Treaty of Karlowitz (1699) marked the decline of the Ottoman's dominance over Europe, and concurrently, Russia emerged as a power in the north. In the eighteenth century, as a result of this change in the political dynamics with regard to international relations, the European powers began to exercise their influence over Wallachia and Moldavia earlier than in the other territories in the Balkan Peninsula. Among the European countries, Russia was one of the first to exert its influence over these principalities. The existence of a secret alliance between Peter the Great and the Moldavian voyvoda Dimitrie Cantemir (1693, 1710-11) at the time of the Prut Campaign (1710-1711) bears testimony to this influence. Following the war, the Danubian Principalities became the basis for a power game mainly among three empires - Habsburg, Russia and Ottoman - and a balance of power was achieved for more than fifty years. However, the Russo-Ottoman War (1768-1774) and the Treaty of Kyuchuk Kainardja (1774) resulted in the unsettling of this balance. As a result, the Danubian Principalities became one of the regions most disputed by Russia and the Ottoman Empire, witnessing involvement from Habsburg at times and later from other European powers.

It appears that, to date, little attention has been paid to this subject, although several scholars have mentioned this topic briefly in their work. The Moldavian (Bessarabian) scholar Grosul did so in his monograph on Russian policy concerning the Danubian Principalities' and Stanford Shaw in his study on the Ottoman Empire during the reign of Selim III. ${ }^{2}$ However, these studies only make superficial reference to the issues pertaining to voyvodas and do not focus on them in the context of international relations. 
Moreover, Russo-Ottoman relations in general during this period have not been the subject of many studies. while there have been an abundance of studies on Russo-Balkan relations. From a Russian perspective, in addition to the abovementioned work by Grosul. several monographs focus not only on Russia's Balkan policy but also on Russo-Ottoman relations in general. ${ }^{3}$ From an Ottoman perspective, the only reliable study thus far is Uzunçarşılı's general history of the Ottoman Empire published by Türk Tarih Kurumu (Turkish Historical Society). ${ }^{4}$

Further, specific topics concerning relations between the Ottoman Empire and the Danubian Principalities during the eighteenth century - the so-called Phanariot period - have been discussed in articles by Romanian scholars. For example, Hatt-l şerîfs (Imperial edicts) ${ }^{5}$ addressed to Wallachia and Moldavia by the Porte, after each Russo-Ottoman War. provided a legal background to the relations between the Porte and the principalities, and several articles have analyzed these edicts. ${ }^{6}$ In particular, the Imperial edicts of 1802, which are one of the main focuses in this article, are known to have altered relations between the Ottoman Empire and the Danubian Principalities. With regard to these edicts, Mihail Guboglu, a Romanian orientalist, edited the original text maintained in the National Archives of Romania and translated it into Russian with a brief explanation regarding its background. ${ }^{7}$ A personal research, conducted in the National Archives in Bucharest, revealed many minute differences between Guboglu's edition and the original text that he had based his translation upon. ${ }^{8}$ In addition, from the Russian perspective, G. N. Seliakh provides an outline of the edicts based on Russian diplomatic documents."

Through such a review of the historiography, the lack of studies regarding not only Russo-Ottoman relations but also the relations between the Ottoman Empire and other European powers in the eighteenth century becomes evident. It would appear that the affairs which took place in the Balkans in the second half of the eighteenth century have been examined only as a part of the 'Eastern Question,' and not in the context of Ottoman-European relations. ${ }^{10}$ In other words, the role of the Porte as a political actor in international politics has been neglected, because researchers have depended solely on Western material. It must be emphasized that the Eastern Question is but one of several approaches to an understanding of affairs in the Balkans, and does not provide us with a detailed or comprehensive understanding. In Ottoman studies, from another 
perspective, the study of diplomatic history or international relations prior to the eighteenth century, is one of the weakest fields of study. " Based on these observations, we should use both Western and Turkish material to pursue the study of Ottoman diplomacy as well as the relations between the Porte and the European powers. Further, based on the results of the considerable number of studies on the Eastern Question, an attempt should be made to comprehensively reconsider the subject of the Balkans in the context of international relations wherein the Ottoman Empire is one of the most important actors.

For the purposes of this study, with regard to primary sources, issues related to the voyvodas and the international status of the Danubian Principalities have been examined using both Russian and Ottoman sources. As a main source from the Russian side, reference was made to a collection of diplomatic and consular reports published in Romania and the former Soviet Union. ${ }^{12}$ From the Ottoman side, several chronicles written by Ottoman official chroniclers ' $v a k^{\prime}$ ' nüvvis' ${ }^{13}$ were referred to. Apart from these, this study also made use of published collections of treaties, transliterated or translated Ottoman documents and several archival documents. ${ }^{14}$

\section{The emergence of voyvodas as a political issue in Russo-Ottoman relations}

\subsection{The status of Wallachian and Moldavian voyvodas prior to the Russo-Ottoman War of 1768-1774}

Wallachia and Moldavia, which were both integrated into the Ottoman Empire as vassal states by the beginning of the sixteenth century, had, in theory, reserved the right to elect their own voyvodas, ${ }^{15}$ even though the rights of these two principalities were largely curtailed by the Sublime Porte. In principle, the voyvodas were elected by the boyars (nobles, boier in Romanian and boyâr in Turkish) from among a limited number of upper-class boyars known as 'osul domnesc, and the results of these elections were confirmed by the Ottoman authorities. However, despite the existence of this rule, beginning around the second half of the sixteenth century, the Porte directly chose the voyvodas de facto. At times the Porte would intervene in the election, and if the elected candidate exhibited an anti-Ottoman attitude, the election results would be rejected. ${ }^{16}$ Nevertheless, the principle that voyvodas should be elected from 
among local boyars was maintained until the beginning of the eighteenth century. In the sixteenth and seventeenth centuries, Poland neighboring Moldavia to the south made frequent attempts to bring the voyvodas, and especially the Moldavian voyvodas, under its influence, and at times the Habsburg Empire and Ukrainian Kazaks became involved. ${ }^{17}$ However, during this period, Western Europe was predominantly influenced by the Ottoman Empire. Hence, issues pertaining to the voyvodas were specific only to Polish-Ottoman relations and did not involve many other European countries or affect Ottoman-European relations.

It is widely accepted by scholars that the Treaty of Karlowitz (1699) was a major turning point in Ottoman history, particularly from a perspective of Ottoman-European power relations. As a result of this treaty, the international environment surrounding the Danubian Principalities changed considerably. The cession of Transylvania to Austria, by the Porte, resulted in their bordering the Habsburg Empire, and concurrently, in northern Europe, Russia emerged as a rival of the Ottoman Empire. In particular, Russia attempted to advance into the Balkans, appealing to the principalities as a protector of the Orthodox Church and a liberator from the 'yoke' of the Ottoman rule. In response, the Moldavian voyvoda Dimitrie Cantemir and the Wallachian voyvoda Constantin Brâncoveanu (as Wallachian voyvoda 1688-1714) both requested Russia's protection, and Cantemir actively collaborated with Russia in the Russo-Ottoman War (17101711).

Although the Russians were defeated, the Porte was forced to take new measures to prevent the principalities from gaining independence from the Ottoman suzerainty. Subsequently, the Porte abolished the indirect appointment of voyvodas and introduced a direct appointment system to strengthen its rule over Wallachia and Moldavia. The newly nominated voyvodas were appointed by the Porte from among several influential families called Phanariots, ${ }^{18}$ since their base was in the Phanar (in Turkish 'Fener') district in Istanbul. These voyvodas were appointed in Istanbul and sent to Bucharest or Iaşi like other Ottoman vâlîs (governors of eyâlet). The Phanariots were a social group, most of whom were Orthodox Christians of Greek-origin, engaged in commerce, shipping and finance. They were needed by the Porte in the seventeenth century due to their financial power and their knowledge of both Europe and European languages. From the second half of the seventeenth century onward, the 
Phanariots were appointed as official translators of the imperial court (Divân-l hümâyûn tercümanlarl) and played an important role particularly in the diplomatic field. From 1711 to 1821 , the voyvodas were appointed to the Danubian Principalities from the Phanariots; however, they were actually only chosen from among less than ten dominant families. This was because, in principle, as a career pattern, the chief translator of the imperial court was nominated to become a voyvoda $a^{19}$ and was thus obligated to pay enormous amounts of money and give gifts to the Sultan, his family and high officials. Therefore, only people with a strong political and economic background could acquire the post. Moreover, although the official term of a voyvoda was three years, they were sometimes replaced earlier because of intense competition among the Phanariot families and the Ottoman high officials' motivation to increase their profits. Thus, in the eighteenth century, the policy adopted with regard to the appointment of voyvodas was inconsistent and lacked long-term perspective, and the appointed voyvodas collected their investment in the principalities with alacrity. Consequently, this exhausted the land and caused dissatisfaction among the boyars and peasantry, ${ }^{20}$ leading to discontentment among the local boyars with regard to the Greeks who had accompanied the voyvoda from Istanbul and occupied high ranks in the administration. The local boyars then turned to foreign countries, particularly Russia, in an attempt to regain the privileges they had lost, making foreign intervention all that much easier. Moreover, contrary to the Porte's expectations, the Phanariot voyvodas were not always loyal and some of them approached France, Habsburg and Russia. Thus, the Ottoman's intention to strengthen its rule over the Danubian Principalities, through the direct appointment of voyvodas, did not always succeed.

\subsection{The Treaty of Kyuchuk Kainardja and the status of Wallachia and Moldavia}

Many scholars agree that the Treaty of Kyuchuk Kainardja (1774) changed the balance of power that had existed between the Ottoman Empire and the European powers. For the Danubian Principalities, the treaty was also significant because according to the stipulations of the treaty, the internal affairs of these principalities and Ottoman-Moldo-Wallachian suzerain-subject relations emerged as international issues for the first time since the Treaty of Karlowitz. Therefore, the Treaty of Kyuchuk Kainardja is an apt starting point for this 
article's analysis, and a more detailed examination of the process whereby the treaty was reached and of its impact are required.

The Russo-Ottoman War in 1768 was more widespread than the previous wars between the two empires. Not only did it cover the Russo-Ottoman frontiers in Europe but also spread over Caucasus and Morea (Greece) and they became battlefields as well. The militarily predominant Russian army advanced into the Danubian Principalities and occupied the capital of Moldavia, Iaşi, in the autumn of 1769 and then advanced into Wallachia and seized its capital Bucharest. Thus, the Ottoman defeat in the principalities was evident. Russia, emphasizing its position as the protector of the Orthodox Church, made an appeal to the people of Wallachia and Moldavia to cooperate. ${ }^{21}$ In response to this appeal, anti-Ottoman uprisings occurred in various places and the local boyars and the clergy sent a delegation to St. Petersburg to petition for the Empress' protection against Ottoman rule. ${ }^{22}$ Additionally, Grigore Alexandru Ghica, the Wallachian voyvoda (in Moldavia 1764-67, in Wallachia 1768-69), also cooperated with Russia by intentionally delaying the supply of provisions to the Ottoman troops. As a result of this behavior, Ghica was removed from his post and fled to Russia. ${ }^{2.3}$

When Russian superiority over the Ottoman Empire and the Danubian Principalities' expectations with regard to Russia became clear, other European countries became involved in the war as well. The Habsburg Empire and Prussia, in particular, took an active part and under pressure resulting from the involvement of these two countries, Russia decided to enter into peace negotiations with the Porte in 1770. Negotiations were undertaken, first in Giurgiu, then in Focşani and Bucharest. However, the two parties were unable to reach an agreement, and the war raged on.

As a result of Pugachev's revolt, which had spread along the Volga and presented a serious threat to the Russian government, Russia was required to end the war in haste, and in June 1774, in Kyuchuk Kainardja, a small village near Silistra, negotiations were reopened. Approximately two weeks later, on July 10,1774 , a peace agreement comprising twenty-eight articles and two separate articles was signed by both plenipotentiaries. ${ }^{24}$

In the last conference, held in Bucharest, the Russian delegation had presented the Ottoman representatives with a draft of a peace treaty that included stipulations regarding the Danubian Principalities..$^{25}$ This time, the Ottoman 
representatives accepted the treaty with some modifications. Article 16 of the treaty addressed the status of Wallachia and Moldavia. Therein the Porte assured the freedom of Christianity in the principalities, a tax exemption for two years, the right of the Russian diplomatic representative in Istanbul to voice his opinions concerning the affairs of the Danubian Principalities, and so on.

Although Article 16 did not address the subject of voyvodas, in the draft presented at the negotiations in Bucharest, Russia had demanded that the Porte reappoint the former voyvoda Grigore Ghica, who was in Russia at the time, as a 'lifelong voyvoda' to Moldavia 'with a solemn pledge that the Porte would neither replace him for any reason nor insult and menace him in any way. ${ }^{26}$ Russia had protected Ghica with the intention of using him as a puppet in the future, and it is evident from this clause that it aimed to extend its influence into Moldavia through this pro-Russian voyvoda. It can be implied then that Moldavia had turned into a puppet state in the hands of Russia. Subsequently, this clause would play a major role in Russia's advance into the Balkans.

However, in the negotiations held at Kyuchuk Kainardja, Russia had conceded some points and their stipulation concerning the appointment of Grigore Ghica was excluded. Nevertheless, the Porte was forced to agree to his appointment as a Moldavian voyvoda, and after the conclusion of this treaty, Ghica was officially nominated as a 'lifelong voyvoda.'27

With regard to economy and finance, the treaty did not bring many improvements to the Danubian Principalities. However, the significance of this treaty lies in the fact that clause 10 in Article 16, which stipulates Russia's voice concerning the affairs of the principalities, paved the way for Russia to officially involve itself in issues pertaining to Wallachia and Moldavia. In other words, following this treaty, affairs of the principalities that had previously been the internal affairs of the Ottoman Empire became international in scope. Some have conjectured that owing to this treaty, Russia obtained the right to protect Orthodox Christian subjects in the Ottoman Empire. This is not true. Article 7 of the treaty states that the Orthodox Christian subjects in the Ottoman Empire must be protected by the Porte, and not by Russia. ${ }^{28}$ Thus, the Danubian Principalities were an exception. The Russian voice in the affairs of Wallachia and Moldavia was not as strong as the right of protection. But this did represent the beginning of Russia's deepening involvement in the affairs concerning, first, the principalities and, later, the entire Balkan region, aided by the right to open 
consulates anywhere in the territory of the Ottoman Empire (Article 11). Moreover, although there was no clause about voyvodas in Article 16, Russia succeeded in placing its puppet at an important vantage point in one of the Ottoman vassal states, and eventually this would provide Russia with the opportunity to penetrate the Danubian Principalities as well.

With the granting of new rights to Russia in the treaty of 1774 , the balance of power among Russia, Western Europe and the Ottoman Empire, which had brought stability to the eastern part of the European continent for more than fifty years, shifted. Consequently, the Habsburg Empire and other European powers began to take precautions against Russia's further advancement into the Balkan region and hence were obligated to take an interest in issues pertaining to that region. Thus, we can conclude that Article 16 of the Treaty of Kyuchuk Kainardja carried immense importance, not only for the Danubian Principalities and the Balkans, but also for the balance of power and the international order.

\subsection{Issues regarding voyvodas after the Treaty of Kyuchuk Kainardja}

As mentioned above, the pro-Russian Grigore Alexandru Ghica was appointed as a lifelong Moldavian voyvoda. Following Ghica's appointment, Alexandru Ipsilanti, who was appointed to Wallachia after the treaty, also petitioned Russia for 'lifelong' status, ${ }^{29}$ which action suggests that Russia had become the other patron of the Danubian Principalities. Concurrently, in the Ottoman Empire, there was an increasing dissatisfaction among the Phanariots since the chance of their being appointed to the post of vorvoda had been reduced. As a result, there soon appeared a movement to eliminate Ghica from his post. The Ottoman government was also dissatisfied with Ghica and the Russian presence in Moldavia. One of the reasons for their dissatisfaction was that the imperial family and high officials were, consequently. no longer able to earn large sums of money and receive gifts with each nomination of a new voyvoda. ${ }^{30}$ On learning that the Moldavian voyvoda and boyars intended to place their state under Russian protection, in an act of protest against the Ottoman cession of Bukovina to the Habsburg Empire, ${ }^{31}$ the Porte decided to eliminate Ghica. In order to achieve this, the Porte sent an agent, kapıcıbaşı Karahisârî-zâde Ahmed, to Iaşi who, in October 1777, succeeded in Ghica's assassination. ${ }^{32}$ With the elimination of the lifelong pro-Russian voyvoda, Russia's intended advance into the Danubian Principalities collapsed. 
In 1781, Russia allied itself with the Habsburg Empire, and by the end of 1782 , both made representations to the Porte with regard to the following three issues: (1) the navigation of trading vessels in the Black Sea, (2) Crimea and (3) the Danubian Principalities. ${ }^{33}$ With regard to the first issue, the Porte signed a commercial treaty with Russia in June $1783 .{ }^{34}$ With regard to Crimea, Catherine II declared the annexation of the Crimean Khanate by Russia and the Porte approved it in $1784 .{ }^{35}$ Finally, with regard to the Danubian Principalities, the Porte was obliged to accept the demands put forward by Russia and the Habsburg Empire, owing to diplomatic pressure, and an agreement was signed as a form of convention (sened) in the beginning of $1784 .{ }^{36}$ In connection with the principalities, the most important point of this convention appears to have been that the tributes and other taxes sent to the Porte were fixed in order to prevent excessive exploitation. With regard to the voyvoda, it was stated that '...unless a proved violation occurs, the voyvoda is not to be replaced.... ${ }^{37}$ The inclusion of a passage on the voyvodas was the first instance of a regulation concerning voyvodas in an official diplomatic agreement between Russia and the Ottoman Empire. As a result of this convention, the possibility that a voyvoda might stay in the post for a longer period of time - an outcome that Russia had coveted was renewed.

Even after the convention had been agreed upon and despite this stipulation, voyvodas were often replaced. It was evident that Russia had hoped to keep pro-Russian voyvodas in their posts for a long period but apparently this stipulation had been ineffective. In general, voyvodas could gain profit legally as well as illegally; therefore, any form of violation was easily identified by both empires. Even if a voyvoda complied with the regulations, sometimes other Phanariots, aiming to succeed to the post, threatened him and forced him to resign. The Wallachian voyvoda Alexandru Ipsilanti's resignation in $1782^{38}$ and Mihail Suţu's subsequent resignation in $1786^{39}$ are examples of this. In fact, the Ottoman Empire appeared to regard the 1784 convention lightly. For example, in 1785, the Porte appointed Alexandru Mavrocordat II (Firaris, 1785-86). The new voyvoda was known to be a Russophile because, like Grigore Ghica, he had fled to Russia during the Russo-Ottoman War. ${ }^{40}$ Nevertheless, he was appointed as a voyvoda. This fact clearly indicates that the Porte believed that they could remove him with little difficulty. As expected, he was replaced by Nicolae Mavrogheni (1786-90) the very next year. 
Thus, Russia's ambition to keep pro-Russian voyvodas in their posts for longer periods was not achieved through the convention of 1784 .

The year 1787 witnessed another Russo-Ottoman War. Russian troops easily occupied Moldavia, and in keeping with an alliance between Russia and Austria, Austrian troops advanced into Wallachia. Despite this Russian and Austrian predominance, their complete victory over the Ottoman Empire was not accepted by other European powers. In 1789, Sweden declared war against Russia, and Great Britain, Prussia and the Netherlands formed an alliance. Moreover, the French Revolution had an extremely large impact on Europe; consequently, the Habsburg Empire promptly signed a peace treaty with the Porte in Svishtov, and Russia, following in Habsburg's footsteps, called for an armistice. Prior to negotiations, Russia made clear to the Porte that the Danubian Principalities would be returned, albeit with several conditions attached ${ }^{41}$ In their negotiations, Russia focused on issues pertaining to Russian-occupied Moldavia and an agreement was reached with regard to several conditions such as a two-year tax exemption and the free movement of Moldavian subjects within their country. The Treaty of Iaşi, signed in January 1792, served to reconfirm the validity of past agreements regarding the Danubian Principalities but there was an absence of stipulations concerning the voyvodas. ${ }^{42}$

However, it would appear that the Ottoman's attitude toward issues pertaining to the voyvodas changed during the Russo-Ottoman War (1787-1792). Following the armistice in 1790, there arose the need to nominate a new Moldavian voyvoda. In the grand vizierial summary (telhis), presented by the official deputy of the Grand Vizier (sadâret kaymakamı) to the Sultan on the nomination of a new voyvoda, the Ottoman officials placed significant emphasis on "who among the candidates is the most loyal to the Porte and who can exclude Russian influence from Moldavia' instead of "who will pay the most." ${ }^{3}$ Further, the law (kânûnname) issued to Moldavia after the treaty stipulated that among the translators in the Imperial Council (dîvân-ı hümây ŷn tercümanlart) a very loyal one to the Porte would be nominated as voyroda. ${ }^{+4}$ Based on this stipulation, Alexandru Moruzi (in Wallachia 1792-96, 1799-1801, in Moldavia 1792), who was said to have relations with France, was nominated as the Moldavian voyvoda.

Owing to the French revolution and the existence of an anti-Russian alliance, the Ottoman Empire was able to avoid a large-scale territorial loss despite its military inferiority. However, this war, undoubtedly, had a great impact on the 
Porte. The Ottoman Empire had been forced to recognize, clearly and seriously for the first time, that their empire had grown extremely weak and that it would be unable to recover lost territory by force. This then led to a military reform known as 'Nizâm-ı cedîl', and they began to feel threatened with regard to the security of the Danubian Principalities. This change in the Ottoman attitude towards the nomination of voyvodas can be regarded as evidence of their changing consciousness with regard to the international situation as well.

\section{Issues pertaining to voyvodas in the Imperial edicts of 1802}

\subsection{Internal disorder in the Balkans and the involvement of France in the affairs of the Danubian Principalities}

After the French Revolution, Russia established the first diplomatic principles regarding the prevention of France's influence. Russia's Balkan policy was not an exception. In fact, in the first half of the 1790 s, France actively began to advance into the Balkans, and when the Porte officially recognised the revolutionary government, it gave France permission to establish its consulate in Bucharest, hoping to diminish Russian influence over the Danubian Principalities. ${ }^{45}$ In this context, Russia began to carefully observe France's activities in the Danubian Principalities, particularly the relations between France and the families of the voyvodas. Russia initially believed that Mihail Suţu, the Moldavian voyvoda (1792-95), would be beneficial to them. However, when it became known that his son in Istanbul shared good relations with France, Russia began to doubt him. In 1795, when the French consulate opened in Bucharest, Russia feared that the French might have influence over the voyvoda's family, and the Russian Minister to the Ottoman Empire, V. P. Kochubey, complained of Mihail Suţu's illegal actions and demanded that the Porte remove him from his post. The chief translator at the Imperial council, Alexandru Callimachi, was the strongest candidate to become the next voyvoda, and he displayed a favorable attitude towards Russia in order to acquire the post with their help. Owing to pressure from Russia and other Phanariots, Suţu resigned. This incident illustrates Russia's anxiety with regard to an increase in French influence over the Danubian Principalities.

France sent agents to the area south of the Danube and succeeded in establishing relations with local notables known as ' $a^{\text {' } y a ̂ n . ' ~ D u r i n g ~ t h i s ~ p e r i o d, ~}$ 
the $a^{\natural} y \hat{a} n$ s disregarded the central authority and fought one another to expand their own territory. Since the power of the central authority was very weak and it was unable to suppress these conflicts, the area south of the Danube was in anarchy and was divided among several powerful $a^{\prime} y a \hat{n} \mathrm{~s}$. Of these, Osman Pazvand-oğlu of Vidin had a significant impact on Wallachia and Russo-Ottoman relations. ${ }^{46}$

Aiming to widen his territory, Osman Pazvand-oğlu battled with his rivals for many years, causing a state of disorder and anarchy in Northern Bulgaria. ${ }^{47}$ In order to maintain his power, he retained a large number of private soldiers (kapı halkı). The land beyond the Danube was a good source of riches, which he exploited to support his soldiers. He often sent his troops north of the Danube to plunder the area around Oltenia, and he repeatedly demanded money and provisions for Vidin from the Wallachian, and at times even Moldavian voyvodas, threatening them with further attack if they refused. ${ }^{48}$ To suppress this disorder, the Porte dispatched troops to Vidin and besieged the fortress on three separate occasions, in 1795, 1798 and 1800. All of these expeditions ended in failure, however. Moreover, on each occasion the Porte was compelled to offer Osman honorary offices such as kapıcıbaşlık or ve-îrlik to placate him.

During these expeditions, the Porte imposed a heavy burden on Wallachia and Moldavia, providing the salary and supply of provisions for the Ottoman soldiers, offering their units to Vidin and so on. The Ottoman soldiers who entered Wallachia to attack Vidin were of diverse origin and not well organized, and as a result, they plundered towns and villages on their way. Owing to these heavy burdens and miserable conditions, especially in Oltenia, a strong voice asking for Russian intervention gradually emerged from among the Wallachian boyars around $1800 .{ }^{49}$ However, despite these requests, Russia hesitated to intervene in the affairs of the Danubian Principalities because of international relations at that time.

France defeated the Habsburg troops in Italy, acquired the Ionian Islands and the Albanian coast in accordance with the Treaty of Campo Formio in 1797, and agitated the Greek insurrection. This caused a strain in French-Ottoman relations. Then, France's invasion of Egypt in the following year compelled the Porte to end all relations with France. who had been a potential ally since the sixteenth century. ${ }^{50}$ This situation led the Porte to forge an alliance with Great Britain and its strongest rival, Russia. ${ }^{51}$ This represented a drastic change in 
Ottoman foreign policy. As a result of this alliance, the Porte, who had until then maintained neutrality among the European states, joined the anti-Napoleonic coalition.

Given these circumstances, Russia needed to avoid strong intervention in the affairs of the Danubian Principalities. In fact, in 1798, before establishing an alliance with the Porte, Russia had offered to send an auxiliary corps of six thousand soldiers to Vidin..$^{52}$ However, once an alliance with the Ottoman Empire was forged, Russia did not repeat their offer and only requested that the Porte take proper measures to quell the disorder in Wallachia.

\subsection{The Imperial edicts addressed to Wallachia and Moldavia in $\mathbf{1 8 0 2}$}

In 1800, while the third siege of Vidin continued, Osman Pazvand-oğlu petitioned the Porte several times through the Wallachian voyvoda, but it was Russia that played the most important role as a mediator. Osman sent his agents with letters to the Russian Vice-Consul in Bucharest and the Russian Minister in Istanbul requesting that they forward his petition to the Porte. This is to say that Osman asked Russia to put pressure on the Porte, and in order to compel Russia to pressure the Porte further, Osman decided to send his soldiers to Wallachia again in 1802 , sending them in groups this time. ${ }^{53}$

From April 1802 onward, there was severe turbulence in Wallachia. Since Tepedelenli Ali Paşa, whom the Porte had appointed as the Governor of Rumelia (Rumeli vâlisi) and the Chief Commandant of the Rumelian front (Rumeli tarafi seraskeri) ${ }_{54}$ did not abandon Yanya (Ioannina), his base, Osman Pazvand-oğlu dispatched large numbers of troops to Wallachia. They seized Oltenia and advanced further, to Bucharest. As a result of this sudden attack, there was widespread panic in Bucharest, and many boyars, foreign diplomats and even the voyvoda himself fled to Kronstadt (Braşov). Following this incident, the boyars and ecclesiastics who had escaped sent a petition to Alexander I, a copy of which was sent to Vasily Tomara, the Russian Minister in Istanbul, requesting Russian assistance in their return to Wallachia. ${ }^{55}$ Based on this petition, Tomara dispatched a diplomatic note to the Porte suggesting that action be taken to improve the disastrous situation in the Danubian Principalities. In the note, he introduced issues that pertained to the voyvodas and demanded that the Porte observe the regulations agreed to in the Russo-Ottoman Convention of 1784. In addition, he wrote: 'It is important and inevitable that the Sublime Porte and the 
signatory (Tomara - A. M.) enter into negotiations and arrive at an agreement to establish proper conditions concerning the term of both voyvodas. ${ }^{56}$

Concurrently, in St. Petersburg, on receiving the petition from Kronstadt, the Russian government sent instructions to Tomara dated June 28, 1802, wherein Alexander I ordered him to inform the Porte that if the damage caused by Pazvand-oğlu reached Moldavia, Russia would dispatch its troops to the Danubian Principalities. ${ }^{57}$ On receiving this order, Tomara delivered a second note to the Porte, wherein he made more concrete demands with regard to the principalities. ${ }^{58}$ Aside from the exemption of taxes, the official term of the voyvodas was the principal subject of the note, and Tomara proposed a term of seven years or more. The instructions from St. Petersburg had not included the term of 'seven years.' Hence it is evident that this term was introduced by Tomara himself, based on his own judgment. However, this was not an idea that originated with Tomara, since the seven-year term was described in a request sent to him by the representative (kapı kethüdâsı) of the Wallachian voyvoda Alexandru Suţu, in Istanbul. ${ }^{54}$ Three days later, in response to Tomara's note, the Porte proposed 'four years' as the official term for voyvodas, but Tomara was not satisfied with this response.

Therefore, on July 21, 1802, seeing that effective measures had not been taken even after his first demarche, Tomara delivered another diplomatic note to the Porte. ${ }^{(6)}$ In the note he, once again, insisted that the official term of the voyvodas be seven years. In the event of a dismissal prior to the completion of seven years, he suggested that the Porte inform Russia, in advance, so a joint decision could be made as to whether or not the voyvoda had committed an illegal action. With regard to this issue, he presented another note to the reisülküttâb, Mehmed Rauf Efendi the same day, wherein he demanded that the former Moldavian voyvoda, Constantin Ipsilanti, be nominated as the new Wallachian voyvoda. ${ }^{61}$ This demand was in accordance with the petition that had been made by the boyars in Kronstadt, ${ }^{62}$ and Tomara accepted this request because of Ipsilanti's good relations with Russia. C. Ipsilanti was not popular among the Ottoman high officials and was only supported by reisülküttâb and sadâret kethüdâsı. At the time of his nomination as a Moldavian voyvoda in 1799 , it is believed that Ipsilanti paid less money to the high officials than his predecessors. ${ }^{64}$

These two diplomatic notes are a reflection of Russia's intentions regarding 
issues pertaining to the voyvodas. In other words, Russia had expected that after the convention with the Porte in 1784, the frequent change of voyvodas resulting in a heavy financial burden on the people of the Danubian Principalities - would cease, pro-Russian voyvodas would remain in their posts for longer periods and anti-Russian voyvodas could be replaced more easily than before by pointing out their illegal actions. However, despite these expectations, there was no visible change in the situation even after the convention because of severe competition among the Phanariots for the post of voyvoda and economic dissatisfaction on the part of the Ottoman high officials. In the 1790s, when the French influence gradually reached the Danubian Principalities, Russia sought more certain and practical means of appointing pro-Russian voyvodas, keeping them in their posts as long as possible and preventing the Porte from appointing and dismissing voyvodas at will. In order to achieve this goal, Russia fixed the official term of voyvodas at seven years in the first note and made it necessary for the Porte to inform it in advance in the case of a voyvoda's early dismissal. In the second note, Russia insisted on the appointment of Constantin Ipsilanti, a pro-Russian, as the new Wallachian voyvoda.

According to Tomara's notes, the negotiations continued for a month. Before the final agreement, the Porte accepted Russia's proposal to nominate Constantin Ipsilanti, and on August 31, 1802, he was appointed as the Wallachian voyvoda. Concurrently, Alexandru Moruzi, the former Wallachian voyvoda (1792-96, 1799-1801), was appointed as the Moldavian voyvoda. Prior to his appointment, Ipsilanti had repeatedly asked Tomara to also nominate him as a voyvoda. ${ }^{65} \mathrm{Al}$. Moruzi was C. Ipsilanti's uncle and served as a Moldavian voyvoda during almost the same period when Ipsilanti was the Wallachian voyvoda (1799-1801). Since it was known that Al. Moruzi had close relations with France, Tomara hesitated to accept Ipsilanti's request. However, when Al. Moruzi pledged his loyalty to Russia and Ipsilanti also assured it, he finally consented. ${ }^{66}$

Finally, in September 1802, both sides reached an agreement and, in the second half of the month, two Imperial edicts (fermâns) for Wallachia and Moldavia were issued. Russia insisted that the content of the agreement be established as an act between two empires, but the Ottoman Empire claimed that it should be in the form of ferman since issues pertaining to Wallachia and Moldavia were its own internal affairs. Ultimately, Russia compromised. ${ }^{67}$ With regard to the official term of the voyvodas and the issue of their dismissal, the 
Porte accepted Russia's proposal almost completely. A term of seven years was agreed upon, and the stipulation concerning a voyvoda's dismissal was as follows: 'In case an illegal action appears during his (the voyvoda's - A.M.) reign, the Russian ambassador will be informed by the Porte, and after verification by both sides, if the suspicion of the aforementioned voyvoda is evident and certain, only then will his dismissal be approved. ${ }^{2}$ (8

Incidentally, Russia's rival France had little influence during the negotiations, although they had acquired prestige in Constantinople before 1798. Pierre Ruffin, the French chargé d'affaires to the Ottoman Empire, ${ }^{69}$ who had been confined in the Seven Towers (Yedikule) according to the Ottoman custom, was released in 1801, but France was unable to regain its prior influence in Istanbul until a new French ambassador arrived in Istanbul in the end of 1802.

Thus, by taking advantage of the disorder in the Balkans, the change of international relations around the Ottoman Empire and the absence of French influence in Istanbul, Russia - to a large extent - obtained the right to be allowed involvement with regard to voyvodas and other issues concerning the Danubian Principalities. On the other hand, as a result of reluctantly made edicts, the Ottoman right to freely control the voyvodas was largely restrained. Their consequent dissatisfaction would eventually lead the Porte to turn towards France.

\section{The voyvodas' dismissal in 1806 and its impact on Russo-Ottoman relations}

\subsection{The Ottoman Empire and its relations with Russia and France after 1802}

After the peace treaty of 1802 , France dispatched General Brune to Istanbul as a plenipotentiary ambassador, and as a result, diplomatic relations between the Ottoman Empire and France were completely normalized. The new ambassador attempted to re-establish French influence over the Porte, as it had been before the Egyptian expedition, and one of his most important missions was to separate the Porte from Great Britain and Russia. He actively approached the Porte and sought cooperation from it, pointing out that the British troops were inciting the amîrs (commanders or governors) of Egypt to rebel against the central authority. Meanwhile, the British ambassador demanded neutrality from the Porte in the British-French war. ${ }^{70}$ 
Simultaneously, Franco-Russian relations deteriorated, and as a consequence, the principle goal of Russian foreign policy was to maintain an alliance with the Ottoman Empire and to prevent it from approaching France. Therefore, in accordance with this policy, the Russian government dealt with the affairs of the Danubian Principalities with caution, in order not to give the Porte the impression that Russia was still intervening in its affairs. For example, the Russian government prohibited the General Consul in Iaşi and the Vice-Consul in Bucharest from making demarches to the voyvodas based on their own judgment. Further, the Russian government stated that if there was a need to make a demarche, the General and Vice-Consuls were obliged to ask for prior permission from the Foreign Minister in St. Petersburg or the Russian Minister in Istanbul. ${ }^{71}$ When Pazvand-oğlu Osman Paşa ${ }^{72}$ once again demanded money and provisions from the Wallachian voyvoda early in $1803,{ }^{73}$ Constantin Ipsilanti and the Russian Vice-Consul in Bucharest requested that the government of St. Petersburg send Russian troops to Wallachia. In response, the Foreign Minister A. R. Vorontsov, clearly rejected this possibility and made it evident that Russia would not take any measures other than demarches, through the Minister, to the Ottoman Empire. Vorontsov explained that the presence of Russian troops in the Danubian Principalities for the maintenance of public order would give France the opportunity to dispatch its troops to Morea for the same reason. ${ }^{74}$

After Russia severed its diplomatic relations with France in 1804, because Napoleon had declared himself 'Emperor,' the diplomatic activities of the European ministers in Istanbul intensified. France urged the Porte to acquiesce to the title of 'Emperor,' and Selim III was favorable towards this. ${ }^{75}$ However, the Porte suspended the making of any official answer because there was still distrust regarding France among the Ottoman high officials. ${ }^{76}$ Consequently, at the end of 1804, Russia proposed to the Porte that they renew their defensive alliance of 1798, which was due to expire at the end of 1805 . Besides strengthening Russo-Ottoman relations, the principal aim of Russia's proposal was also to prevent France from approaching the Porte. Another motive behind Russia's proposal was that it expected to reinforce the stationary troops that were based in the Ionian Islands (Yedi Ada Cumhuriyeti) through the enactment of a new treaty. ${ }^{77}$ Since the Porte hoped to maintain its alliance with Great Britain, it accepted Russia's proposal and entered into negotiations. The Porte did, however, refuse the following two stipulations in Russia's draft. First, given 
the possibility of a French attack in the future, Russia would dispatch ten to fifteen thousand soldiers in the Danubian Principalities and Great Britain would send five thousand soldiers to Morea. This was on the condition that the Russians and British would not interfere in internal affairs. Second, with regard to ' $r e$ ' $\hat{a} y \hat{a}$ ' (or 'non-Muslim Ottoman subjects') the Porte would improve the conditions of Christian subjects in Rumelia and would give them the same rights enjoyed by Muslim subjects, with the exception of paying 'harâc' (land tax). ${ }^{78}$ Although the second stipulation would be fulfilled in 1839, at the time, the Ottoman Empire rejected it. In September 1805, after a long period of negotiations, both sides agreed to a renewed treaty that was valid for nine years. ${ }^{79}$

At the time that these negotiations were carried out, the situation in Europe was not clear. Although France was comparatively dominant on the continent, Great Britain maintained its control over the Mediterranean. His triumph in the Battle of Austerlitz in December 1805, ensured the dominance of Napoleon and France on the European Continent. To the regret of the Porte, news of the French victory arrived in Istanbul just one day after the mutual ratification of the renewed Russo-Ottoman Treaty. Soon after, a French envoy was sent to officially inform the Porte of France's triumph in Austerlitz. In a confidential dialogue with the Ottoman high officials, the French envoy proposed that the Porte renounce all previous agreements with Russia regarding the Danubian Principalities, including the imperial edicts of 1802, and that France would secure and preserve Ottoman territorial integrity. ${ }^{80}$ Although the Porte did not accept this proposal and maintained a neutral stance, its political attitude towards France gradually became more favorable.

In the beginning of 1806, the Ottoman Empire finally acknowledged Napoleon Bonaparte as Emperor of France. Then, by April 1806, the Porte declined Russia's proposal that Russian fleets should be allowed to pass through the Bosporus Straits ${ }^{81}$ even though this proposal had been made in accordance with a newly ratified treaty. It is evident that the immediate cause for the change in the Ottoman approach towards France was the result of the French victory in Austerlitz. However, Ottoman's distrust of Russia, even though they were allies at the time, should also be taken into account when considering this change of attitude. In addition to the Imperial edicts to the Danubian Principalities in 1802, the Ottoman Empire was disturbed by several Russian activities such as the presence of Russian troops on the Ionian Islands, the annexation of Georgia in the 
Caucasus, the suspicion of incitement and support of the Serbian Revolution, and the large number of Russian troops based near the Russian-Moldavian border. As a result of all these factors, the Porte would gradually sever its ties with Russia and prepared for war against it.

In the beginning of 1806, Sultan Selim III who considered the disorder in the Balkans caused by the Serbs, Osman Pazvand-oğlu and other $a^{\prime} y a ̂ n$ s to be the main reason for foreign intervention, decided to dispatch Nizâm-ı cedîd askeri, a new Western-style military corps that he had founded, to the Balkans. While the official explanation for this decision was the suppression of the Serbian Revolution, in fact, the Sultan's intention was to introduce his reform programs to the Balkans ${ }^{82}$ and to prepare for a future Russian attack. ${ }^{83}$ In response to this series of Ottoman actions based on a change in their attitude, Russia began to make its own preparations for war while continuing its efforts to maintain the alliance with the Ottoman Empire. The Foreign Minister Budberg stated, 'I think Russia needs to maintain its foreign policy towards the Ottoman Empire because a war between Russia and the Ottoman Empire would only serve to fulfil Napoleon's purpose. Hence, regardless of his designs to break RussoOttoman relations, we must not be hasty in severing relations with the Ottoman Empire. ${ }^{84}$

\subsection{The change of voyvodas in 1806}

In July 1806, the French government, determined to take decisive measures to break the Russo-Ottoman alliance, dispatched General Sebastiani to Istanbul as their new ambassador to the Ottoman Empire. Issues related to the Danubian Principalities were an ideal means by which France could separate the Porte from Russia. As soon as the new ambassador arrived in Istanbul, he requested that the Porte dismiss both the voyvodas, stating that they both, under the influence of Russia, had supported the Serbian uprising. ${ }^{85}$ The Porte had also been inclined to replace these voyvodas whom they had unwillingly appointed in 1802, under pressure of Russia, and complaints regarding the long rule of the voyvodas had increased not only among the Ottoman officials but also among the Phanariots. The former Moldavian voyvoda, Alexandru Suţu, who was replaced by Moruzi in 1802 provides one example. Aiming to regain his post, Suţu lobbied the high officials to sever all ties with Russia. Subsequently, by the end of 1805, Italinsky, the Russian Minister in Istanbul, remonstrated to the 
Porte with regard to Suţu's activities. ${ }^{86}$ Soon after, a deputy to Foreign Minister Adam Jerzy Czartoryski ordered Italinsky to make a demarche to the Porte and ensure that the voyvodas would not be replaced before the completion of their seven-year terms. ${ }^{87}$ The above suggests that in Istanbul actions were being taken to remove Ipsilanti and Moruzi from their posts. After considering this issue for a week, on August 24, 1806, the Porte decided to replace the Wallachian voyvoda, Constantin Ipsilanti with Alexandru Suţu, and the Moldavian voyvoda, Alexandru Moruzi with Scarlat Callimachi, the chief translator of the Imperial Council. ${ }^{88}$ These dismissals were executed without any advance notification to Russia although such had been stipulated in the agreement of 1802 .

This incident does not imply, however, that the Ottoman Empire had decided to definitively cut ties with Russia and ally with the French. Even after the replacement of both the voyvodas, the Porte maintained its neutrality and made attempts to avoid a conclusive severance from Russia. It is evident that the peace treaty signed between France and Russia on July 20, 1806 in Paris affected the Porte's decision. According to the treaty, the independence and territorial integrity of the Ottoman Empire were to be preserved. The Porte was informed of the contents of this treaty through a letter from Napoleon addressed to Selim. ${ }^{89}$ The Porte did not anticipate that the dismissal of the voyvodas and violation of the diplomatic agreement would result in the severance of the Russo-Ottoman alliance because of this stipulation in the Peace of Paris and the military predominance of France.

Nevertheless, contrary to the Porte's anticipation, Russia took a firm stand against this incident and regarded these sudden dismissals as a final change in Ottoman diplomatic policy. The Russian Minister in Istanbul Italinsky immediately protested against this decision and demanded that the departure of the newly appointed voyvodas for the principalities be aborted. ${ }^{90}$ In addition, based on instructions from St. Petersburg, he demanded that the Porte restore Constantin Ipsilanti and Alexandru Moruzi to their old posts and assure them that they could serve the remainder of their seven-year terms. At the same time, he informed the Porte that if his demands were not accepted, he would leave for Russia.." On the other hand Sebastiani, the French ambassador in Istanbul, requested that the Porte prohibit the Russian fleets from passing through the Bosporus Straits; in other words, he requested that the Porte annul the RussoOttoman alliance. ${ }^{92}$ As a result, the Porte was presented with a very difficult 
choice from both sides, and thus, it attempted to delay the making of a decision. However, on October 13, Italinsky delivered an ultimatum to the Porte. With the help of mediation by the British ambassador, the Porte attempted to appease the situation by restoring one of the two voyvodas. But, Italinsky did not change his attitude. Some officials in the Porte regarded their relationship with Great Britain as the most important, and therefore, they were apprehensive about the deterioration of British-Ottoman relations in the event the Russo-Ottoman alliance was renounced. Moreover, some officials appreciated that the Empire was not in the position to go to war against Russia, owing to a lack of preparation. ${ }^{93}$ Taking all these issues into account, on October 15,1806, the Porte finally decided to restore the dismissed voyvodas to their old posts. ${ }^{94}$

Although Italinsky dispatched a courier with this news to St. Petersburg, the Russian government did not receive it until November 5, 1806. ${ }^{95}$ By this time, Alexander I had already ordered the commander-in-chief of the Russian army, based near the border of Moldavia, to cross over into Moldavia on October 28, $1806 .{ }^{96}$ Consequently, although the Porte had compromised with Italinsky and restored the voyvodas, Russian troops invaded the Danubian Principalities and commenced the Russo-Ottoman war, a war which would last until 1812.

Even if the Porte had eliminated the pro-Russian voyvodas, one of whom Al. Moruzi - was not, in fact, so devoted to Russia, Russia would not have suffered any heavy losses since the activity of Russian consuls and merchants in the principalities would not have been limited and the advance of other European powers would not have been accelerated. Nevertheless, since the regulations concerning the appointment and dismissal of voyvodas occupied an important place in Russia's Balkan policy in the Imperial edicts of 1802 and in the international situation at that time, the replacement of the voyvodas in 1806 was regarded by Russia as a definitive change in Ottoman foreign policy from a pro-Russian to a pro-French stance. In this way, issues pertaining to the voyvodas made a large impact on Russo-Ottoman relations and became the direct cause of the Russo-Ottoman war.

\section{Conclusion}

This article has examined a series of issues related to the voyvodas of the Danubian Principalities, in the context of Russo-Ottoman relations. Previous 
studies on the Danubian Principalities and Russo-Ottoman relations in the eighteenth and nineteenth centuries, which were mentioned in the 'Introduction,' revealed that Russia strengthened its influence over the Danubian Principalities in the second half of the eighteenth century. However, these studies only offered a general analysis of a variety of subjects and did not analyse any one subject deeply. In contrast, this article has focused on one concrete subject - namely voyvodas - making use of both Russian and Ottoman documents. Questions pertaining to the Wallachian and Moldavian voyvodas began with the Treaty of Kyuchuk Kainardja in 1774. Through this treaty, Russia obtained the voice and the right to intervene in the affairs of the principalities while also succeeding in the placement of a voyvoda, Grigore Ghica, who was a puppet of the Russian government, in Moldavia. Although the Russian advance into the principalities was foiled by the assassination of this voyvoda, thereafter Russia aimed to place pro-Russian persons as voyvodas and extend the length of their terms. Meanwhile, the Ottoman Empire made attempts to hinder this Russian advance into the principalities by emasculating their diplomatic agreement with Russia. With the French influence emerging in the Balkans in the 1790s, Russia took advantage of the disorder in the Balkans caused by the $a^{6} y a ̂ n s$ and by changes in international relations around the Ottoman Empire, and consequently, compelled the Porte to issue new regulations concerning the Danubian Principalities. The Imperial edicts (fermâns) of 1802 were diplomatic agreements that actually stipulated the seven-year term for voyvodas and presented Russia with the opportunity to participate, in part'. in the nomination and dismissal of voyvodas. On issuing these edicts, the Porte was forced to nominate two Phanariots, recommended by Russia, as voyvodas. These edicts, with which the Ottoman Empire was discontented, presented France with the ideal opportunity to break the Russo-Ottoman alliance after French-Ottoman diplomatic relations had been normalised at the end of 1802. When the French gained predominance on the continent, the Ottoman Empire gradually leaned toward the French, and in the summer of 1806 , the Porte decided to violate the agreement of 1802 by replacing the voyvodas, without prior notification to the Russian government. Despite the Ottoman's expectation that, owing to France's predominance, they could evade a war, this incident was regarded by Russia as an obvious change in the Ottoman's diplomatic course, and consequently, it led both empires to war.

In this article, two significant points have been made clear. First, after the 
Treaty of Kyuchuk Kainardja, issues pertaining to Wallachian and Moldavian voyvodas, which were an internal affair of the Ottoman Empire until 1774, became a matter of international importance. Second, after 1802, issues related to voyvodas occupied an important place among Russia, France and the Ottoman Empire as they had even a symbolic significance in the Ottoman diplomatic course. The first point supports the predominant opinion that the Treaty of Kyuchuk Kainardja marked the turning point in relations among the Ottoman Empire, Russia and Western Europe. The second point shows that issues pertaining to the voyvodas that had been an internal affair of the Ottoman Empire until 1774 would become, only thirty years later, some of the most important and disputed issues among the Ottoman Empire, Russia and Western Europe. Thus, the analysis of issues pertaining to Wallachian and Moldavian voyvodas in this article demonstrates concretely that after the Treaty of Kyuchuk Kainardja these three 'worlds' were in even closer contact with one another with regard to issues related to the Danubian Principalities and, as a result, Russia and the Ottoman Empire were rapidly integrated into the Western state system.

\section{Notes}

1. Г. С. Гросул, Дунайские княжества в политике России 1774-1806 г2., Кишинев, 1975.(hereafter cited as $\Gamma p o c y \Omega)$

2. S. J. Shaw, Between Old and New: The Ottoman Empire under Sultan Selim III 1789-1807, Cambridge, 1971.

3. Век Екатерины II: Россия и Балканы, Москва, 1998; Александр I. Наполеон и Балканы, Москва, 1997.

4. I. H. Uzunçarşılı, Osmanl tarihi, vol. 4, part 2, pp. 174-188. Akdes Nimet Kurat, a Turkish scholar famous for his study on Russo-Ottoman relations, has mainly focused on the nineteenth and twentieth centuries, paying little attention to relations during the eighteenth century. A. N. Kurat, Türkive ve Rusya, Ankara, 1970, pp. 24-40.

5. In Ottoman paleography, 'hatt-l şerîf' or 'hatt-l hümâyûn' means what the Sultan writes on paper, in person, therefore, more correctly speaking, it must be called 'Imperial order (fermân) with Sultan's sign of approval,' but customarily it is called just 'hatt-l şerît'. For further details, see Mübahat S. Kütükoğlu, Osmanlı Belgelerinin Dili (Diplomatik), İstanbul, 1998.

6. M. M. Alexandrescu-Dersca, 'Rolul hatişerifurilor de privilegii în limitarea obligaţilor către Poartă (1774-1802)', Studii. Revistă de istorie, 11-6(1958), pp. 101-119; Al. Vianu, 'Aplicarea tratatului de la Küciük Kainargi cu privire la Moldova şi Tara Romînească (1775-1783),' Studii. Revistă de istorie, 13-5(1960), pp. 71-104. 
Issues pertaining to Wallachian and Moldavian royvodas

7. М. Губоглу, 'Два указа (1801г.) и священны іі рескрипт (1802 г.), связанные с турецко-русско-румынским отнопениями'. Востоные источники по истории народов Юго-Восточной и Lентральной Европь. т. 2. Москва, 1969, pp. 238-274.

8. Arhivele naţionale istorice centrale (the Romanian National Archives), inv. 'Documente turceşti,' nr. 1149. Guboglu surmises that this text is a copy from a later period, around 1811.

9. Г. Н. Селях, 'Русско-гурецкое отношение 1802 г. о дунайских княжествах', Bonpocb uстории, 1961/12, pp. 195-202.

10. For example, J. A. R. Marriot, The Eastern Question: A Historical Study in European Diplomacy, Oxford, 1917; M. S. Anderson. The Eastern Question 1774-1923, Macmillan, 1966.

11. In 2004, the first comprehensive study on Ottoman diplomacy was published. A. Nuri Yurdusev ed., Ottoman Diplomacy: Conventional or Unconventional?, Palgrave Macmillan, 2004.

12. Documente privind istoria Romîniei: colecția Eudoxiu de Hurmuzaki (seria nouă), vol. 1 , 'Rapoarte consulare ruse (1770-1796) din Arhiva politica externă a Rusiei Moscova,' Bucureşti, 1962; vol. 4, 1974(hereafter cited as Hurmuzaki); Bнецняя noлиmика Poсcии ХІХ и начала XX века. Москва. 1960)-(hereafter cited as ВПР).

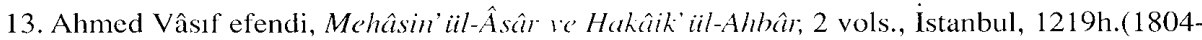
05), (hereafter cited as Vâstf 1): Ahmed Vâssf efendi. Mchâsin' ül-Âsâr ve Hakâik' ül-Ahbâr: haz. Mücteba Ilgürel, Ankara, 1994 (cited as lâstf 2). The former covers the period from 1166h.(1762)-1188h.(1774) and the latter. transliterated in the modern Turkish alphabet. covers 1196h.(1782)-1201h.(1787) with the author's brief career and some information regarding manuscripts. Ahmed Cevdet Paşa, Târih-i Cevdet, tertîb-i cedîd(new edition), ikinci tab"a(the second printing). 12 vols.. Der Sa âdet, 1309h(1891-92) (hereafter cited as Cerdet); Ahmed 'Âsım efendi, 'Âsmm târihi, 2 vols., İstanbul, f.d..

14. Gabriel effendi Noradounghian. Recueil d'actes internationaux de l'Empire Ottoman, 4 vols.. Paris, 1897-1900; de Testa. Recueil des traités de la Porte Ottomane avec les Puissances Étrangères, vol. 9. Paris, 1898: G. F. de Martens ed., Recueil de traités d' Alliance, de Paix, de Trève, de Neutralité. de commerce, de limites, d'échange etc. et de plusieurs autres actes servant à la connaissance des relations étrangères des Puissances et états de l'Europe, 2nd ed., 8 vols., Gottingue. 1817-1835: Mu' 'âhedât mecmû'asi, 5 vols., 1295h-1298h; V. Veliman, Relațiile româno-otomane 1711-1821: documente turceşti, Bucureşti, 1984.

15. In Ottoman sources, 'vovoda' was used most generally as a term designating the ruler of the principalities. This word of Slavic origin usually means tax collector from 'hâss,' a tenure possessed by Sultans, their families or high dignitaries in Ottoman history. We can also often find the term 'bey' in Ottoman documents. Besides these two terms, 'tekfûr,' 'hâkim,' and 'bân' are also used although they appear less often. See M. Guboglu, Paleografia şi diplomatica turco-osmană, studiu şi album. Bucureşti. 1958, p. 84. In European texts, 
the terms 'duke,' 'prince,' 'hospodar' and the like are used.

16. For an example of Ottoman intervention, see V. Panaite, 'Power Relationships in the Ottoman Empirc: The Sultans and the Tribute-paying Princes of Wallachia and Moldavia from the Sixteenth to the Eighteenth Century,' International Journal of Turkish Studies, vol. 7(2001), pp. 33-34; M. Maxim, 'L'autonomie de la Moldavie et de la Valachie dans les actes officiels de la Porte au cours de la seconde moitié du XVIe siècle,' Revue des Études Sud-Est Européennes, 15-2(1977), p. 211.

17. For example, in 1568 the Polish king Zygmunt II August demanded that the Porte should never appoint the voyvodas of the Danubian Principalities without Polish assent, and then a Moldavian voyvoda, Bogdan Lăpuşneanu (1568-72), also tried to enter into matrimony with a woman from a szlachta family and showed allegiance to the Polish king. Because of this, he was displaced by the Porte. See I. H. Uzunçarşll, Osmanlı tarihi, vol. 3, part 2, p. 166; M. A. Mehmet ed., Documente turceşti privind istoria româniei, vol. 1, Bucureşti, 1976, pp. 93-94. The Wallachian voyoda Radu Şerban (1602-10), the Moldavian voyvoda Gaspar Graţiani (1619-20) in the seventeenth century, and other voyvodas who fled to Poland after being displaced by the Porte because of their close relations, sometimes deteriorated Polish-Ottoman relations. (I. H. Uzunçarş1l1, op. cit., pp. 173-175)

18. For Phanariots, see Symposium L'époque phanariote. 2I-25 octombre 1970: à la mémoire de Cleobule Tsourkas, Thessaloniki, 1974; A. Pippidi, Tradiţia politică bizantină în ţările române în secolele XVI-XVIII, Bucureşti, 1983.

19. Cevdet, vol. 6, p. 298.

20. We should take notice that several voyvodas like Constantin Mavrocordat (in Wallachia 1730, 1731-33, 1735-41, 1744-48, 1756-58, 1761-63, in Moldavia 1733-35, 1741-43, 174849, 1769) or Alexandru Ipsilanti (in Wallachia 1774-82, 1796-97, in Moldavia 1787-88) stayed in their post more than three years and carried out reforms. For the reforms of Constantin Mavrocordat, see F. Constantiniu, Constantin Mavrocordat, Bucureşti, 1985.

21. Россия и освободительная борьба молдавского народа протия османского ига (17691812), Кишинев, 1984, р. 20.

22. For the text of this petition, see ibid., pp. 23-31; Hurmuzaki, vol. 1, pp. 87-89.

23. Cevdet, vol. 2, p. 78 .

24 . The text of this treaty was prepared in three languages, Russian, Italian and OttomanTurkish. The Russian delegation signed on Russian and Italian texts, while the Ottoman representatives signed on Italian and Turkish texts. These original texts have yet to be discovered. The Russian text is in Полное собрание законов российской империи, series 1 (1649-1825), vol. 19, pp. 957-967. The Italian text is in G. F. de Martens ed., op. cit., vol. 2 , pp. 286-322. The Ottoman-Turkish text is in Mu'âhedât mecmû́ast, vol. 3, pp. 254-273 and in Cevdet, vol. 1, pp. 357-370.

25. The text is in Е. И. Дружинина, Кнчук-кайнарджийский мир 1774 года (его подготовка и заклнченис), Москва, 1955, pр. 345-346.

26. In Vâsıf's chronicle it is written that on Grigore Ghica's death someone from his family 
will succeed him in the post of voyvoda. Such a description, however, does not exist in the Russian draft. Vâsı l, vol. 2, p. 243.

27. A copy of the berat (imperial diploma) on his appointment dated September 27, 1774 (1188 receb 21) is kept in Arhivele naţionale istorice centrale (the Romanian National Archives), inv. 'Documente istorice,' pachet DLXXXI/64.

28. For this question, sec Roderic H. Davison, "Russian Skill and Turkish Imbecility": The Treaty of Kuchuk Kainardji Reconsidered,' Slavic Review, 35-3(1976), pp. 463-483.

29. Hurmuzaki, vol. 1, p. 97.

30. The imperial decree 'kânunname' issued in 1793 to both principalities set the amount of money which a newly appointed voyvoda should pay to sadr-l a zam, sadâret kethiidâst, reisülküttâb and other high officials (caize-i voyvodalık). According to this decree, the amount exceeded one third of the tribute (cizye) of each principality. Considering the amount paid to the Sultan and his family, we may estimate that upon appointment, the voyvoda needed to pay an amount of money equivalent to more than half of the yearly tribute of that principality. See, V. Veliman, Relatiile româno-otomane 1711-1821: documente turceşsti, Bucureşti, 1984, pp. 599-614; M. A. Mehmet, 'O nouă regulamentare a raporturilor Moldovei şi Ţării Româneşti faţă de Poartă la 1792 (O carte de lege — Kanunname - în limba turcă)', Studii. Revistă de istoric', 20-4(1967), pp. 691-708.

31. Россия и освободительная борьба .иолдавского народа протио осматского ига (17691812), Киннев, 1984, р. 93.

32. Cevdet, vol. 2, p. 78; Tahsin Gemil. 'Mărturii din arhivele turceşti referitoare la sfî̀rşitul tragic al domnului Moldovei Grigore Al. Ghica (1777), Revista arhivelor, 1984/3. pp. 289-298.

33. For the content, see Cevdet, vol. 2. pp. 352-354.

34. For the text, see Mu'âhedât me'mû'ast. vol. 3, pp. 284-319; G. Noradounghian, Recueil d'actes internationaux de l'Empire' Ottoman, vol. 1, pp. 351-373.

35. Mu'âhedât mecmû'ası, vol. 3. pp. 319-320; G. Noradounghian, op. cit., vol. 1, pp. 377378.

36. For the text, see $M u^{\prime}$ 'âhedât mecmú 'ası. vol. 4. pp. 2-4; Arhivele naţionale istorice centrale, inv. 'Documente istorice,' pachet DLXXXI/92. The French translation is in D. A. Sturdza şi C. Colescu-Vartic ed., op. cit., pp. 192-195.

37. The original text is '...tahkîk olunmuş bir töhmet vukû' bulmakça beyler azl olunmamak ....'

38. Cevdet, vol. 2, p. 169.

39. Cevdet, vol. 3, pp. 263-264.

40. Vâstf 2, pp. 210, 380-381.

41. Cevdet, vol. 5, p. 158.

42. For the text of this treaty, see $M u^{\prime}$ âhedît me'mî'asl, vol. 4, pp. 5-13; Cevdet, vol. 5 , pp. 330-339: D. A. Sturdza şi C. Colescu-Vartic ed.. op. cit., pp. 219-225.

43. Cevdet, vol. 5, pp. 327-330. 


\section{Akitsu Mayuzumi}

44. V. Veliman, op. cit., p. 604.

45. For the activities of the first French consul in Bucharest, see Camariano-Cioran, 'L'activité d'Emile Claude Gaudin, premier consul de France à Bucharest,' Revue Roumaine d'histoire, 9(1970), pp. 251-260.

46. For a survey of his life and activity, see R. Gradeva, 'Osman Pazvantoğlu of Vidin: Between Old and New,' in Frederick F. Anscombe ed., The Ottoman Balkans 1750-1830, Princeton, 2006, pp. 115-161.

47. Seе В. Мутафчиева, Кърджалийско време, София, 1977; Y. Özkaya, Osmanlı İmparatorluğunda Dă̆lı İsyanlart(1791-1808), Ankara, 1983.

48. Hurmuzaki, vol. 4, pp. 135-138, 262-263, 270-271.

49. ibid., pp. 297-298, 315-317.

50. For French-Ottoman relations of this period, see E. Z. Karal, Fransa-Mtsir ve Osmanlt Imparatorluğu (1797-1802), Istanbul, 1938; i Soysal, Fransız ihtilâli ve Türk-Fransız Diplomasi münasebetleri (1789-1802), Ankara, 1964 (reprint, 1999).

51. For the text of this Russo-Ottoman treaty of 1799 , see, Mu' âhedât mecmú $^{\prime}$ ast, vol. 4 , pp. 19-28; Gabriel effendi Noradounghian, op. cit., vol. 2, Paris, 1897, pp. 24-27.

52. V. Ciobanu ed., Europe and the Porte: New Documents on the Eastern Question, vol. 2 (Swedish Diplomatic Reports, 1798-1799), The Centre for Romanian Studies, 2001, pp. 106-107.

53. For details of the relations between Osman Pazvand-oğlu and Russia, see A. Mayuzumi, 'Pazvand-oğlu Osman Pasha, Russia and The Danubian Principalities: from the end of the 18 th century to the beginning of the 19th century.' in Studii şi cercetări de turcologie contemporanč-Omagiu profesorului Mihai Mavim. 2004, Cluj-Napoca, pp.109-115.

54. Cevdet, vol. 7. p. 154. The Porte often used cooperative a vâns to subdue the more rebellious ones. In the case of Osman Pazvand-oğlu, the Porte supported his rival, Tirsiniklioğlu İsmail, but to no effect. Therefore, at the beginning of 1802 the central government asked Tepedelenli Ali Paşa to suppress Osman Pazvand-oğlu by conferring the abovementioned office. The Russian Minister in Istanbul, Vasily Tomara wrote, 'If he is loyal to the central government, he will put all a'yâns in order as before.' $B \Pi P$, vol. 1 , p. 195.

55. ibid., p. 710.

56. ibid., p. 239.

57. ibid., pp. 232-233.

58. ibid., pp. 241-243.

59. Hurmuzaki, vol. 4, pp. 393-394.

60. ibid., pp. 250-254.

61. BПР, vol. 1, pp. 254-255.

62. Hurmuzaki, vol. 4, pp. 394-395.

63. Upon his nomination as Moldavian voyvoda in 1799, the Emperor Pavel I ordered Tomara to give him his full support. BחP, vol. 1, p. 58. But he was dismissed in the end of 1801 . 
Issues pertaining to Wallachian and Moldavian voyvodas

64. ihid., p. 270.

65. ibid., p. 302.

66. Armand Gosu, 'The Third Anti-.Vapoleonic Coalition and the Sublime Porte,' International Journal of Turkish Studies. 9/1-2(2003), p. 219: V. Mischevca and P. Zavitsanos, Principele Constantin Ypsilanti 1760-1816, Chişinău, 1999, pp. 59-62. However, Russia always looked on Moruzi with suspicion.

67. ВПР, vol. 1, p. 701. However, Russia viewed these edicts as an official diplomatic agreement. On February 28, 1803 Russia sent a note to the Porte saying that it approved the new stipulations concerning the Danubian Principalities. This was actually Russia's ratification. For the text of the fermân adressed to Wallachia, see М. Губоглу, 'Два указа (1801 г.) и священный рескрипт (1802 г.), связапные с турецко-русско-румынским отношениями,' Восточные источники по истории народов Юго-Восточной и Центральной Eвропы, т. 2, Москва, 1969, pp. 252-272; Cevdet, vol. 7, pp. 352-361. There are two copies in the Romanian National Archives, Documente turceşti, nr. 1149 and 2440. For its French translation, see G. Noradounghian. op cit., vol. 2, 1900, pp. 55-67. For the fermân addressed to Moldavia, see Arhivele naţionale istorice centrale, Microfilm Turcia, rola 1, c. 19-22 (copied from Topkapı Sarayı Müzesi Arşivi, E-3999/1). Romanian oricntalist Mustafa A. Mehmet translated these wo edicts into Romanian. M. A. Mehmet ed., Documente turceşti privind istoria României. vol. III(1791-1812), Bucureşti, 1986. pp. 167-188.

68. The original text is: 'müddet-i merkûme içinde töhmeti zûhurunda cânib-i Devlet-i Aliyye'den Rusya elçisine ihbâr olunub bu vechile tarafeynden ba'de'l-tahkîk voyvoda-i mûmâileyh fî nefs'il-emr müttehem olduğu zâhir ve müttehakik olur ise yalnız ol hâlde azli câ'iz ola'.

69. For his life, see H. Deherain, La vie de Pierre Ruffin: orientalist et diplomat 1742-1824, 2 vols., Paris, 1929-30.

70. Cerdet, vol. 7, p. 260.

71. Гросул, p. 166.

72. Osman had sent his agents and letters to the Russian vice-consul in Bucharest several times and requested Russia's mediation between the Porte and himself. He promised that he would remove all his troops from Wallachia. only if he was permitted by the Porte and could have the title of 'vezîr' restored. Expecting that disorder in Wallachia would be settled. Russia put pressure on the Porte and as a result. in August 1802, the Porte permitted Osman and returned the title of 'vezîr' to him. Thus he became Osman 'Paşa.' Cevdet, vol. 7. p. 161; Hurmuzaki, vol. 4, p. 415.

73. Cevdet, vol. 7, p. 256. His demand began just after a French agent visited him in Vidin in the end of the previous year. I do not have any documents with which to confirm this at present, but it is possible that the French agent told him of French support at that time. I plan to study relations between predominant a 'yans. and European countries in the future. 74. BПР, vol. 1, pp. 389-390.

75. It is well known that Selim was a Francophile as he had corresponded with the French 
king Louis XVI when he was the crown prince. See I. H. Uzunçarş1l, 'Selim III'ün Veliaht Iken Fransa Kralı Luii XVI. ile Muhabereleri,' Belleten, 2/5-6 (1938), pp. 191-246.

76. Cevdet, vol. 8, p. 68.

77. As the result of joint operations by the Russian and Ottoman fleets against France in the Mediterranean, in 1800 the Ionian Islands became independent as a republic under the suzerainty of the Ottoman Empire. Even after independence, however, the Russian troops stayed there because of their geopolitical importance in the Mediterranean. Though Russia wanted a reinforcement of troops and easier access there, the treaty of 1798 limited the Russian fleets' navigations in the Bosporus Straits only to wartime. Therefore Russia sought an opportunity to modify this stipulation. C. Tukin, Boğazlar meselesi, 1999. pp. 138-139. For Russian activity in the Mediterranean, see A. М. Станиславская, Poссия $u$ Греция в коние ХVIII - начале ХІХ века: политика России в Ионической республике 1798-1807 г2., Москва, 1976; Русско-англииские отноиения и проблемы средиземноморья, 1798-1807. Москва 1962. And for the Ionian Republic from the Ottoman perspective, see İ. H. Uzunçarşılı, 'Arşiv Vesikalarma Göre Yedi Ada Cumhuriyeti,' Belleten, 1/3-4 (1937), pp. 627-639.

78. BIP, vol. 2, p. 697.

79. For details regarding the background to and the negotiation of this treaty, see Armand Gosu, 'The Third Anti-Napoleonic Coalition and the Sublime Porte,' International Journal of Turkish Studies, 9/1-2(2003). pp. 199-237. This volume was also published as K. Karpat and R. Zens ed., Ottoman Borderland: Issues, Personalities and Political Changes, The University of Wisconsin Press, Madison, 2003. For the text of this treaty, see $M u$ 'âhedât mecmî ası, vol. 4, pp. 35-49 (in Turkish); G. Noradounghian, op. cit., vol. 2, pp. 70-77 (in French); ВПР, vol. 2, pp. $582-594$ (in Russian).

80. Cevdet, vol. 8, p. 46.

81. According to the secret article IV of the 1805 Russo-Ottoman treaty, the Russian fleet could pass through the Bosporus Straits in peace and in war. The Porte, however, declined the Russian proposal, insisting on the possible outbreak of war with France and the neutral position of the Ottoman Empire. ВПР, vol. 3, p. 684; C. Tukin, op. cit., pp. 144-145.

82. Cevdet, vol. 8, p. 61. When the Sultan's decision became clear, almost all $a$ 'yâns in the Balkans who had striven with each other cooperated in opposing this plan. As a result, the Nizâm-l cedîld corps in Edirne had to go back to Istanbul. This is called 'the second Edirne incident (ikinci Edirne vak"ast),

83. From about 1805, the Ottoman Empire began repairing the fortresses along the Dniestr and the Danube. ВПP, vol. 3. p. 79.

84.ibid., pp. 252-253. In instructions from the Minister of Foreign Affairs Budberg to the Russian Minister in Istanbul, Italinsky, dated 30 July.

85. ibid., p. 263.

86. ibid., p. 666.

87. ibid., p. 179. 
Issues pertaining to Wallachian and Moldavian voyvodas

88. Cerdet, vol. 8, p. 74.

89. Ahmed 'Âsım Efendi, 'Âsım tîrihi. vol. 1, p. 182.

90. BПP , vol. 3, p. 285. At that time he did not demand the restoration of the dismissed Ipsilanti and Moruzi, because he thought these former voyrodas might have been killed.

91. ibid., pp. 301-302; 'Âsım târihi, vol. 1, p.182.

92. ВПР, vol. 3, p. 319.

93. Cevdet, vol. 8, p. 76.

94. ibid., pp. 75-76 ; M. A. Mehmel, op. cit., pp. 211-212.

95. ВПР, vol. 3, p. 347.

96. ihid., p. 360. Alexander I had fixed October 13 as the day of the decision, but without news from Istanbul, he postponed his decision for two weeks. 